\title{
Regulation of Proliferation of Human Colonic Subepithelial Myofibroblasts by Mediators Important in Intestinal Inflammation
}

\author{
Timothy M. Jobson, Charlotte K. Billington, and lan P. Hall \\ Division of Therapeutics, University Hospital, Queen's Medical Centre, Nottingham NG7 2UH, United Kingdom
}

\begin{abstract}
An increase in myofibroblast number may be necessary for wound healing but may also lead to postinflammatory scarring. We have, therefore, studied the role of mediators important in inflammatory bowel disease in regulating proliferation of human colonic myofibroblasts. Using primary cultures of these cells, we have shown increases in $\left[{ }^{3} \mathrm{H}\right]$ thymidine incorporation in response to platelet-derived growth factor $\left(\mathrm{EC}_{50}=14 \mathrm{ng} / \mathrm{ml}\right)$, basic fibroblast growth factor $\left(\mathrm{EC}_{50}=2.2 \mathrm{ng} / \mathrm{ml}\right)$, and epidermal growth factor $\left(\mathrm{EC}_{50}=\right.$ $1.1 \mathrm{ng} / \mathrm{ml})$. Coulter counting of cell suspensions demonstrated increases in cell number with these growth factors along with insulin-like growth factor-I and -II. In addition the proinflammatory cytokines IL-1 $\beta$ and TNF- $\alpha$ produced increases in $\left[{ }^{3} \mathrm{H}\right]$ thymidine incorporation. IL-1 $\beta$ and platelet-derived growth factor together produced an increase in $\left[{ }^{3} \mathrm{H}\right]$ thymidine greater than either agonist alone; this effect was not, however, seen when we examined changes in cell numbers. Finally, we demonstrate a mechanism whereby these responses may be downregulated: vasoactive intestinal peptide $(1 \mu \mathrm{M})$ elevates cyclic AwMP in these cells 4.2-fold over control and produces a dose-related inhibition of platelet-derived growth factor-driven proliferation with a maximum inhibition of 33\% at $1 \mu \mathrm{M}$. (J. Clin. Invest. 1998. 101: 2650-2657.) Key words: inflammatory bowel disease • fibrosis • growth factors $\bullet$ cytokines $\bullet$ vasoactive intestinal peptide
\end{abstract}

\section{Introduction}

Myofibroblast proliferation is seen in response to inflammation in many tissues regardless of the aetiology of the insult. Where damage to an epithelial layer occurs, for example in the skin, proliferation of underlying myofibroblasts may be important for wound healing. It is also recognized, however, that excess myofibroblasts persisting beyond the inflammatory insult may be a risk factor for scarring and pathological remodeling of the tissue $(1,2)$. In the colon, these processes may be important in the pathophysiology of the chronic inflammatory process in inflammatory bowel diseases. In these conditions, ulceration occurs and subepithelial cell growth may therefore be

Address correspondence to Timothy M. Jobson, Division of Therapeutics, University Hospital, Queen's Medical Centre, Nottingham NG7 2UH, United Kingdom. Phone: 115-924-9924. FAX: 115-9422232. E-mail: timothy.jobson@nottingham.ac.uk

Received for publication 30 September 1997 and accepted in revised form 8 April 1998.

J. Clin. Invest.

(C) The American Society for Clinical Investigation, Inc. 0021-9738/98/06/2650/08 \$2.00

Volume 101, Number 12, June 1998, 2650-2657

http://www.jci.org required for resolution of the damage. In longstanding inflammation, however, marked changes in the lamina propria architecture are seen with destruction of epithelial crypts and excess matrix production (3). The cause of this remodeling is unknown, but excess myofibroblast number and, consequently, excess collagen production is a potential aetiological factor.

A number of peptides important in the pathogenesis of ulcerative colitis have potential to regulate myofibroblast number. Growth factors such as PDGF-BB, basic fibroblast growth factor (bFGF), ${ }^{1}$ and EGF are found in the colonic mucosa (4, 5 ), and are mitogens for myofibroblast-like cells derived from other tissues. IGF-I and IGF-II have been shown to be upregulated in animal models of chronic inflammation (6) and have been shown to promote survival of other mesenchymal cells (7). The proinflammatory cytokines IL-1 $\beta$ (8) and TNF- $\alpha$ are upregulated in inflammation of the colon (9), and are thought to play a key role in initiating the inflammatory response (10). The proinflammatory cytokine IL-6 is upregulated in ulcerative colitis (9), as is the antiinflammatory cytokine IL-10 (11), which has a key immunomodulatory role in inflammatory bowel disease (12). There is good evidence that these peptides may be produced locally in the colonic mucosa from either macrophages or other leukocytes in close proximity to myofibroblasts, and that tissue levels may be significantly altered during inflammation.

The role played by neuropeptides in inflammatory bowel disease is unclear, but vasoactive intestinal peptide (VIP) has potentially important immunomodulatory functions (13) and is produced by both nerve endings (14) and inflammatory cells in the lamina propria (15). In addition, eosinophils present in the normal mucosa may secrete VIP. Because the VIP receptor is positively coupled to adenylate cyclase and it is known that elevating cyclic AMP inhibits proliferation in other systems (e.g., human airway smooth muscle cells; 16), VIP could potentially inhibit proliferative responses in subepithelial myofibroblasts.

The factors that regulate intestinal myofibroblast numbers are unknown, but clearly long-term changes in cell number are likely to be important in remodeling of the mucosa. Cell culture models are a useful tool in understanding these processes, but, until recently, in vitro studies of human colonic myofibroblasts have relied on the use of immortal cell lines (17), the growth characteristics of which are likely to be different from nontransformed cells. Studies on primary cultures of human intestinal smooth muscle cells have been performed for a limited number of mitogens $(18,19)$, and although these cells may be important in transmural inflammation and stricture development, they are unlikely to play a role in healing and remodeling in the subepithelial layers. A novel ex vivo model has recently been established that enables pure populations of subepithelial myofibroblasts from adult human intestinal mu-

1. Abbreviations used in this paper: bFGF, basic fibroblast growth factor; VIP, vasoactive intestinal peptide. 
cosa to be available (20). Using these cells, we have studied the role of mediators important in inflammatory bowel disease in driving or inhibiting colonic myofibroblast mitogenesis.

\section{Methods}

Materials. Sterile plasticware was from Costar (Cambridge, MA). All tissue culture materials and reagents were from Sigma Chemical Co. (St. Louis, MO), except for penicillin, streptomycin and amphotericin (pen-strep-fungizone), and PBS, which were from GIBCO BRL (Gaithersburg, MD), and FCS, which was from Advanced Protein Products (Brierley Hill, UK). Recombinant human growth factors were from Peprotech EC Ltd. (London, UK), recombinant human IL-1 $\beta$ was from Genzyme (Cambridge, MA), and human VIP was from Calbiochem (Nottingham, UK). Radiochemicals: $\left[{ }^{3} \mathrm{H}\right]$ thymidine (specific activity: $81.0 \mathrm{Ci} / \mathrm{mmol}),{ }^{14} \mathrm{C}$-labeled cyclic AMP $(26.8 \mathrm{Ci} /$ $\mathrm{mmol})$, and $\left[{ }^{3} \mathrm{H}\right]$ adenine $(52.3 \mathrm{Ci} / \mathrm{mmol})$ were obtained from Amersham International (Amersham, Bucks, UK).

Culture of human colonic myofibroblasts. Primary cultures of myofibroblasts were established as recently described (20). In brief, samples of human adult normal colonic mucosa obtained from resection specimens ( $>5 \mathrm{~cm}$ from the tumor margin) from patients undergoing partial colectomy for carcinoma were separated from the underlying muscularis mucosae by microdissection. Mucosal strips were subsequently denuded of epithelial cells by sequential treatments with EDTA (21). It has previously been demonstrated that myofibroblasts will migrate through basement membrane pores during culture of deepithelialized mucosal samples. Lamina propria lymphocytes, macrophages, and eosinophils also migrate via basement membrane pores (21) and were, therefore, removed with frequent changes of media (RPMI $/ 10 \%$ FCS). Colonies of myofibroblasts appeared after culture of denuded mucosal fragments for $\sim 2 \mathrm{wk}$. These colonies grew to form a confluent monolayer over the subsequent 1-3 wk. At this stage, cells were harvested by incubating for 5-10 $\mathrm{min}$ in trypsin $(0.5 \%) /$ EDTA $(5 \mathrm{mM})$ in PBS at $37^{\circ} \mathrm{C}$ followed by addition of whole growth medium, DME containing $15 \%$ FCS, glutamine $(2 \mathrm{mM})$, penicillin $\mathrm{G}(100 \mathrm{u} / \mathrm{ml})$, streptomycin $(100 \mu \mathrm{g} / \mathrm{ml})$, and amphotericin-B $(0.25 \mu \mathrm{g} / \mathrm{ml})$. Cells were then centrifuged at $275 \mathrm{~g}$ for $10 \mathrm{~min}$ and resuspended in growth medium. Cells were maintained in culture up to passage 12. In general, cells were grown in $75-\mathrm{cm}^{2}$ flasks and split 1:3 at each passage with trypsin/EDTA as described above. For experiments, cells were split from one flask to four 24-well plates and grown over $4-7 \mathrm{~d}$.

Phenotypic verification of human colonic myofibroblasts. Verification of continuing myofibroblast phenotype was achieved by light, electron, and fluorescent microscopy. Phase contrast microscopy was performed using an Axiovert 10 (Zeiss, Oberkochen, Germany) microscope on confluent and subconfluent cultures of human colonic myofibroblasts. Electron microscopy was performed by fixing cells grown on a petri dish using glutaraldehyde and subsequent imaging of ultrathin sections. For immunofluoresence microscopy, cells were grown to confluence in eight-chamber slides (Nunc Inc., Naperville, IL), washed in PBS three times (5 min per wash), and fixed by incubation with permeafix (Orthodiagnostics, Amersham, UK) for 10 $\min$. The presence or absence of cellular proteins was determined using the following mouse monoclonal antibodies: smooth muscle $\alpha$-actin (A2547), vimentin (V6630), desmin (D1033), myosin (M7786), and fibroblast surface protein (F4771; all from Sigma Chemical Co.; all antibodies used at 1:20 dilution). Cells were incubated for 14-18 h with the relevant primary antibody diluted in blocking solution (PBS + $10 \%$ FCS), followed after further washing by rabbit anti-mouse IgG secondary antibody conjugated to fluorescein isothiocyanate for $1 \mathrm{~h}$. Cells were then viewed using a Nikon Diaphot 300 microscope (Melville, NY) under ultraviolet light and photographed.

$\left[{ }^{3}\right.$ H]Thymidine incorporation. Subconfluent cultures (70-90\%) of myofibroblasts in 24-well plates were washed and then incubated in DME containing $0.2 \%$ FCS, PSF, and glutamine for $24 \mathrm{~h}$ to growth arrest cells. Agonists were then added for $24-40 \mathrm{~h}$ as appropriate. $\left[{ }^{3} \mathrm{H}\right]$ Thymidine $(1 \mu \mathrm{Ci} /$ well $)$ was added for the final $16 \mathrm{~h}$ of the incubation. At the end of this period, the supernatant was aspirated and cells were washed twice with PBS before being fixed with methanol $(100 \%) /$ glacial acetic acid $(3: 1)$ for at least $1 \mathrm{~h}$ at room temperature. Two further washes with methanol/water (4:1) were performed before lysing cells with $1 \mathrm{ml}$ of $1 \mathrm{M} \mathrm{NaOH}$ (22). $900 \mu \mathrm{l}$ of the supernatant was transferred to a scintillation vial along with $10 \mathrm{ml}$ scintillation fluid (Packard, Meriden, CT) and counted on an LKB scintillation counter (efficiency $30 \%$ ), results being expressed as disintegrations per minute or as fold stimulation over control.

Determination of cell number. Cells grown in 24-well plates were washed twice with PBS before being incubated for $10 \mathrm{~min}$ at $37^{\circ} \mathrm{C}$ with trypsin/EDTA. Cells were harvested by gentle but repeated resuspension with a pipette and transferred to $10 \mathrm{ml}$ Isoton (Coulter Electronics, Luton, UK) and counted on a Coulter counter using a lower size limit of $15 \mu \mathrm{m}$. This lower size limit was chosen after preliminary experiments demonstrating that the myofibroblasts have a diameter in suspension of 20-30 $\mu \mathrm{m}$, and that a lower limit of $<15 \mu \mathrm{m}$ leads to inclusion of cell debris in the counts.

Determination of cyclic AMP responses. Intracellular accumulation of cyclic AMP was determined using methods previously described in human airway myocyte cultures (23). In brief, confluent cultures of human colonic myofibroblasts were incubated in Hanks/ Hepes buffer (HBSS without $\mathrm{NaHCO}_{3}$, [GIBCO BRL] $48.8 \mathrm{~g}$ and Hepes $26 \mathrm{~g} / 5$ liters, $\mathrm{pH} 7.4$ ) with $2 \mu \mathrm{Ci} /$ well $\left[{ }^{3} \mathrm{H}\right]$ adenine for $3 \mathrm{~h}$ at $37^{\circ} \mathrm{C}$. At the end of this time, cells were washed twice in $1 \mathrm{ml}$ buffer alone and incubated for $20 \mathrm{~min}$ in $1 \mathrm{ml} \mathrm{Hanks/Hepes} \mathrm{to} \mathrm{allow} \mathrm{the} \mathrm{cells}$ to rewarm to $37^{\circ} \mathrm{C}$. All experiments were performed without the addition of phosphodiesterase inhibitors. Agonists were then added and after $30 \mathrm{~min}$, reactions were terminated by the addition of $50 \mu \mathrm{l}$ of concentrated $\mathrm{HCl}$. Cells were then stored at $-20^{\circ} \mathrm{C}$ until rethawing for determination of ${ }^{3} \mathrm{H}$-labeled cyclic AMP by column chromatography as previously described (24); a recovery label of ${ }^{14} \mathrm{C}$-labeled cyclic AMP was added to each sample to correct for variations in recovery between columns. A $100-\mu l$ aliquot from each sample was taken before running on columns and counted for $\left[{ }^{3} \mathrm{H}\right]$ to correct for uptake of the $\left[{ }^{3} \mathrm{H}\right]$ adenine and variation in cell number.

Statistical methods. In general, results have been expressed as mean \pm SEM. Results were compared with control using the paired Student's $t$ test and where multiple comparisons are made significance was confirmed by one-way ANOVA. For increases in cell number, a $95 \%$ confidence interval is calculated, a lower limit $>0$ implying a significant increase (25).

\section{Results}

Verification of myofibroblast phenotype. Because this method of continued culture of intestinal subepithelial myofibroblasts is novel, we have taken steps to verify the phenotype of these cells after repeated passage. In subconfluent cultures, these cells took on a stellate morphology with fine processes extending from all cells (Fig. $1 a$ ). On reaching confluence, the cells became more compact with typical swirls and hillocks. Another typical feature of myofibroblasts is the presence of longitudinally arranged bundles of microfilaments. Filamentous elements were clearly visible, using transmission electron microscopy (Fig. 1c) of ultrathin sections of a monolayer grown on plastic tissue culture dishes.

Immunofluorescence studies revealed similar patterns of staining from passages 5 through 12, and also between donors. Cells stained positive for smooth muscle $\alpha$-actin (Fig. 1, $b$ and $d$ ), as well as the intermediate filament vimentin (Fig. $1 e$ ). Only weak, nonspecific staining was seen with antibodies directed against desmin and fibroblast surface protein and no specific staining was seen for smooth muscle myosin. These 

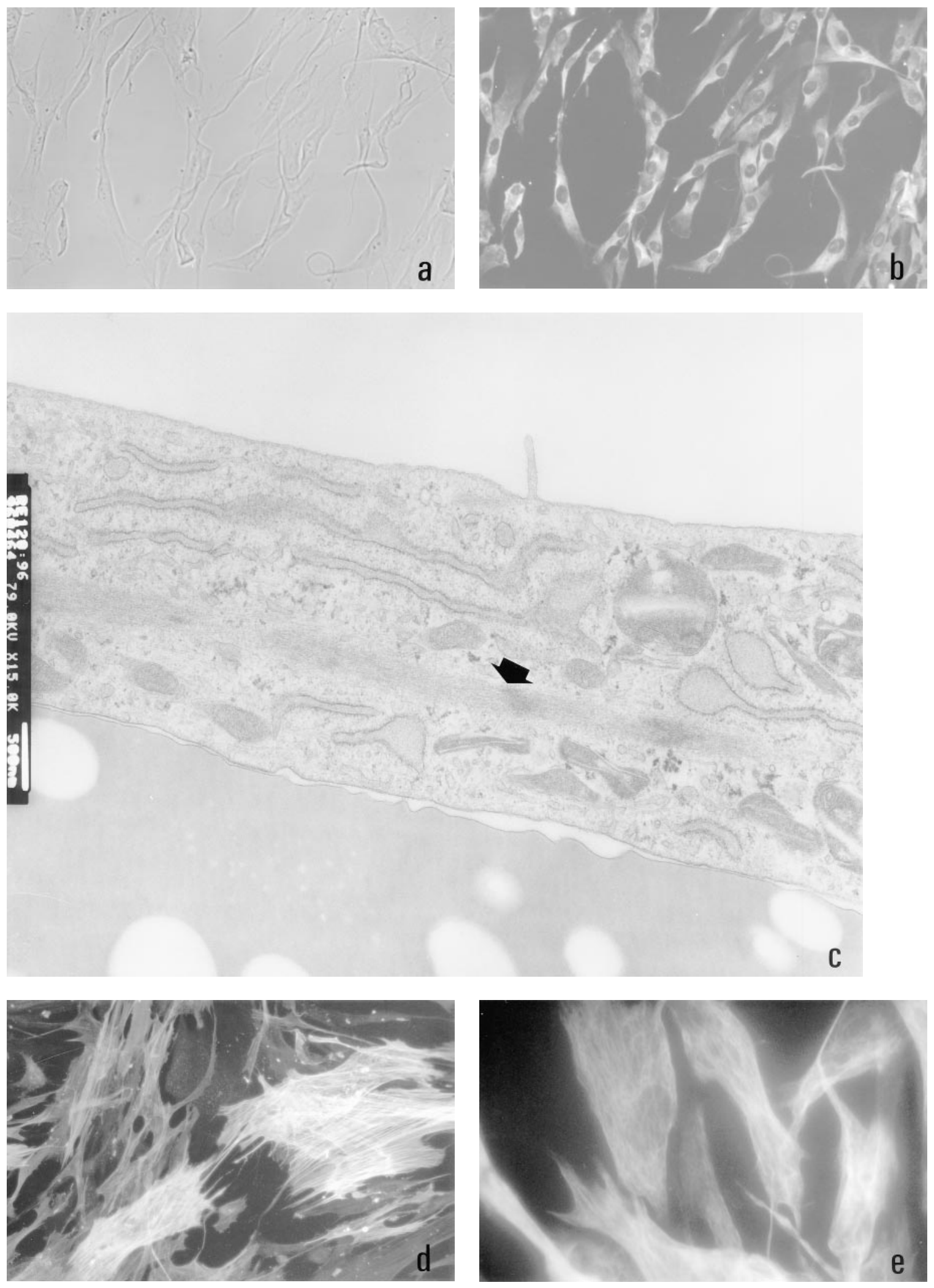

Figure 1. Phenotypic characterization of human colonic myofibroblasts. Cultured myofibroblasts seen by light microscopy (phase contrast) (a) and the same field stained for smooth muscle $\alpha$-actin with FITC-conjugated secondary antibody and viewed under ultraviolet light $(b)$. $(c)$ Crosssection through a cultured cell as seen by electron microscopy with filaments clearly visible (arrow). ( $d$ and $e$ ) Immunofluoresence to smooth muscle $\alpha$-actin and vimentin showing clear filamentous staining. 
data are consistent with these cells being myofibroblasts with phenotypic features similar to myofibroblasts derived from other tissues $(2,26)$, and confirm that no significant phenotypic changes occur while the cells are maintained in continuous culture. Subsequent experiments were therefore performed on cells at passages 5-12.

Growth factors increase uptake of $\left[{ }^{3} H\right]$ thymidine. PDGFBB enhanced $\left[{ }^{3} \mathrm{H}\right]$ thymidine uptake into colonic myofibroblasts in a dose-related manner (Fig. 2). Of all the mitogens tested, it produced the largest increase in $\left[{ }^{3} \mathrm{H}\right]$ thymidine uptake in the myofibroblasts with a maximum fold stimulation over control of 7.0 $\pm 0.5(n=4, P=0.0004)$ in these experiments at a concentration of $100 \mathrm{ng} / \mathrm{ml}$. The apparent $\mathrm{EC}_{50}$ for this response was $14 \pm 1.2 \mathrm{ng} / \mathrm{ml}$, although this may be an underestimate because the response did not reach a plateau over the (physiological) concentration range used in these experiments.

bFGF and EGF produced dose-related increases in [ $\left.{ }^{3} \mathrm{H}\right]$ thymidine uptake in human colonic myofibroblasts. The maximum stimulation of thymidine incorporation with bFGF was $3.0 \pm 0.06$-fold over control $(n=4, P=0.0004)$, whereas with EGF it was only $2.2 \pm 0.25(n=4, P=0.03)$. Significant increases in $\left[{ }^{3} \mathrm{H}\right]$ thymidine incorporation were seen with both these mitogens over a range of physiological concentrations; the $\mathrm{EC}_{50}$ for bFGF was $2.2 \pm 0.48 \mathrm{ng} / \mathrm{ml}(n=4)$ and for EGF it was $1.1 \pm 0.17 \mathrm{ng} / \mathrm{ml}(n=4)$. (Fig. 2). At 0.8 and $4 \mathrm{ng} / \mathrm{ml}$, the

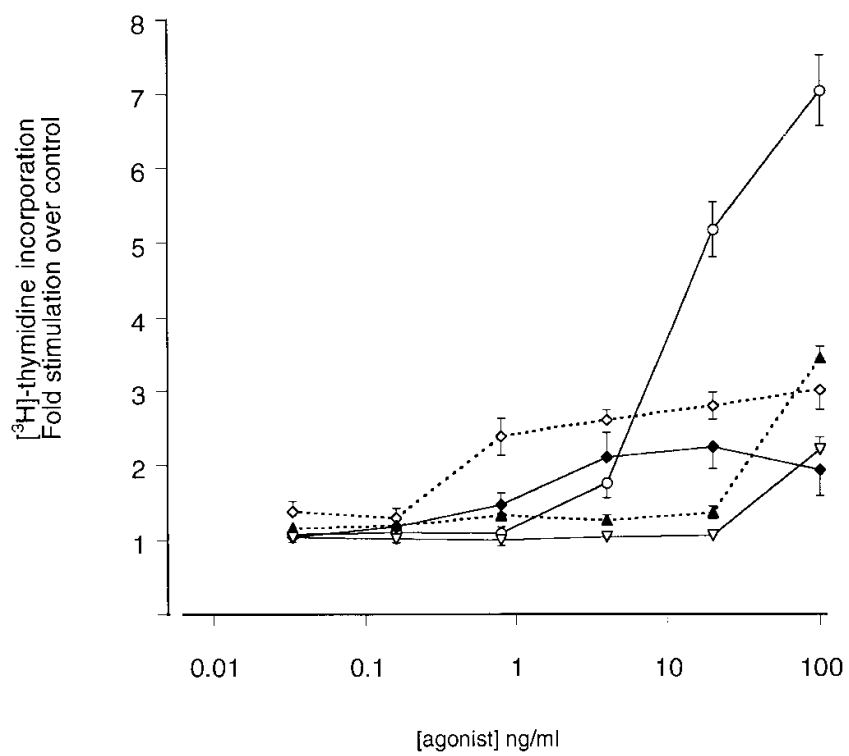

Figure 2. Growth factors stimulate proliferation of human colonic subepithelial myofibroblasts. Cells were growth arrested $(0.2 \%$ FCS, $24 \mathrm{~h}) .\left[{ }^{3} \mathrm{H}\right]$ thymidine incorporation was then measured in cultures stimulated with platelet-derived growth factor $(P D G F-B B, \bigcirc)$, epidermal growth factor $(E G F, \diamond)$, basic fibroblast growth factor $(b F G F, \diamond)$, and $I G F-I, \boldsymbol{\Delta}$ and $I G F-I I, \nabla)$ for $24 \mathrm{~h}$. All data represent mean \pm SEM from four experiments. Within each experiment, data were pooled from triplicate wells. Significant increases over control were seen for PDGF $4 \mathrm{ng} / \mathrm{ml}(P<0.02)$, EGF $0.8 \mathrm{ng} / \mathrm{ml}(P<0.05)$, $\mathrm{bFGF} 0.8 \mathrm{ng} / \mathrm{ml}(P<0.002)$. The apparent $\mathrm{EC}_{50}$ s for the responses were $14 \pm 1.2 \mathrm{ng} / \mathrm{ml}$ for PDGF-BB, 21.1 $\pm 0.17 \mathrm{ng} / \mathrm{ml}$ for EGF and $2.2 \pm 0.48 \mathrm{ng} / \mathrm{ml}$ for bFGF. Significant increases in IGF-I and IGF-II stimulated proliferation were only seen at high concentrations (100 ng/ml) (IGF-I; $P<0.001$, IGF-II $P=0.003)$. mitogenic effect of EGF and bFGF was greater than that of PDGF-BB.

IGF-I and -II did not cause any significant change in $\left[{ }^{3} \mathrm{H}\right]$ thymidine uptake with concentrations within the probable physiological concentration range $(0.1-20 \mathrm{ng} / \mathrm{ml})$, although an increase was seen with $100 \mathrm{ng} / \mathrm{ml}$ to $3.4 \pm 0.17$-fold over control ( $n=4, P=0.0005)$ for IGF-I, and $2.2 \pm 0.17$-fold over control ( $n=4, P=0.003$ ) for IGF-II (Fig. 2).

Growth factors increase cell number. As thymidine incorporation into the cell is only a marker for DNA synthesis, we studied changes in cell number over time. This was achieved by incubating cells for $72 \mathrm{~h}$ in $1 \%$ FCS and, in addition, growth factors and/or cytokines as appropriate. In preliminary experiments with $0-0.5 \%$ FCS, we found a decrease in the number of cells in control wells over the prolonged timecourse of the experiment; therefore, $1 \%$ FCS was routinely included in the medium in these experiments. Any increase in cell numbers is therefore compared with the changes seen in the counts obtained in the control wells at the end of the experimental period to control for variability in the response to FCS $1 \%$. In some experiments, an initial cell count was taken at the beginning of the incubation period, allowing a calculation of change in cell number with control medium over the course of the experiment. This gave a mean increase of $14.8 \pm 2.2 \%(n=4)$ over $72 \mathrm{~h}$. In subsequent experiments where growth factors were added, the results are expressed as additional increases in cell number compared to $1 \%$ FCS alone (at $72 \mathrm{~h}$ ). Significant increases in cell number were seen with PDGF-BB, bFGF, and EGF (all at a concentration of $20 \mathrm{ng} / \mathrm{ml}$; Table I). Surprisingly, IGF-I and -II at $20 \mathrm{ng} / \mathrm{ml}$ (a dose which did not increase $\left[{ }^{3} \mathrm{H}\right]$ thymidine incorporation) did result in an increase in cell number as seen by counting (Table I).

Proinflammatory cytokines stimulate proliferation of human colonic myofibroblasts. IL-1 $\beta$ caused a time- and concentration-dependent increase in $\left[{ }^{3} \mathrm{H}\right]$ thymidine incorporation (Fig. $3 a$ ). The peak response was seen at $0.1-1 \mathrm{ng} / \mathrm{ml}$ with the response tailing off at higher concentrations and was most marked with a total incubation time of $32 \mathrm{~h}$. The $\mathrm{EC}_{50}$ for the response at $32 \mathrm{~h}$ was $15 \pm 2 \mathrm{pg} / \mathrm{ml}(n=4)$. At $24 \mathrm{~h}$, a time at which a marked response to PDGF-BB is seen, there was a smaller response in thymidine uptake. At $40 \mathrm{~h},\left[{ }^{3} \mathrm{H}\right]$ thymidine

Table I. Change in Cell Number in Colonic Myofibroblasts over $72 h$

\begin{tabular}{lcc}
\hline Agonist $(20 \mathrm{ng} / \mathrm{ml})$ & $\begin{array}{c}\text { Percentage increase in cell number } \\
(\text { mean, } n=8) \text { c.f. } 1 \% \text { FCS alone }\end{array}$ & $\begin{array}{c}95 \% \text { Confidence } \\
\text { intervals }\end{array}$ \\
\hline EGF & 61.9 & $23.8-100$ \\
bFGF & 70.7 & $29.6-111$ \\
PDGF-BB & 55.3 & $18.9-91.6$ \\
IGF-I & 31.1 & $18.1-44.2$ \\
IGF-II & 28.2 & $13.6-42.8$
\end{tabular}

Changes in cell number in human colonic subepithelial myofibroblasts stimulated with growth factors (all at $20 \mathrm{ng} / \mathrm{ml}$ ). Cell number was determined by Coulter counting trypsin-harvested cells from 24-well plates (particles $>15 \mu \mathrm{m}$ ) after incubation for $72 \mathrm{~h}$ with $1 \%$ FCS and with additional growth factors, as indicated. Cell numbers are expressed as a percentage increase over counts obtained from wells containing $1 \%$ FCS alone. All data represent mean from eight experiments. Within each experiment, data were pooled from triplicate wells. 
a

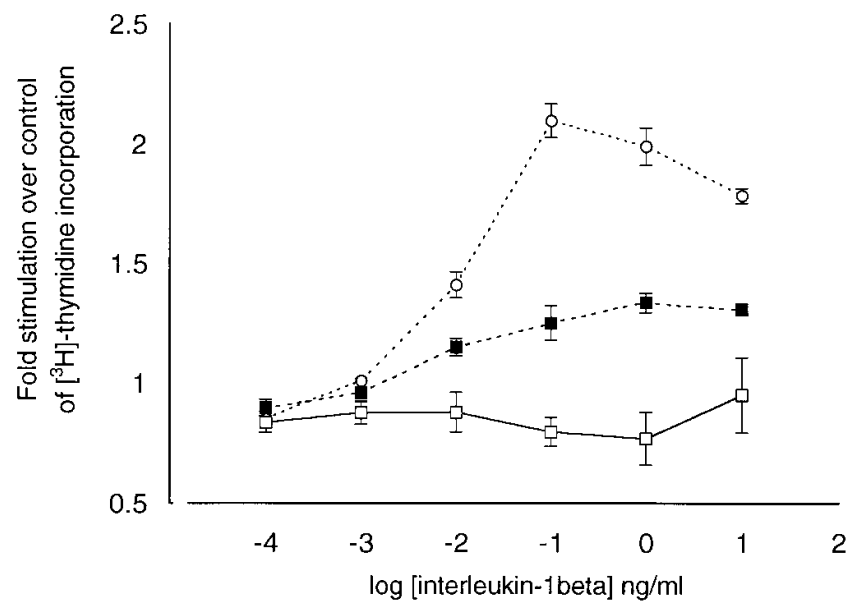

b

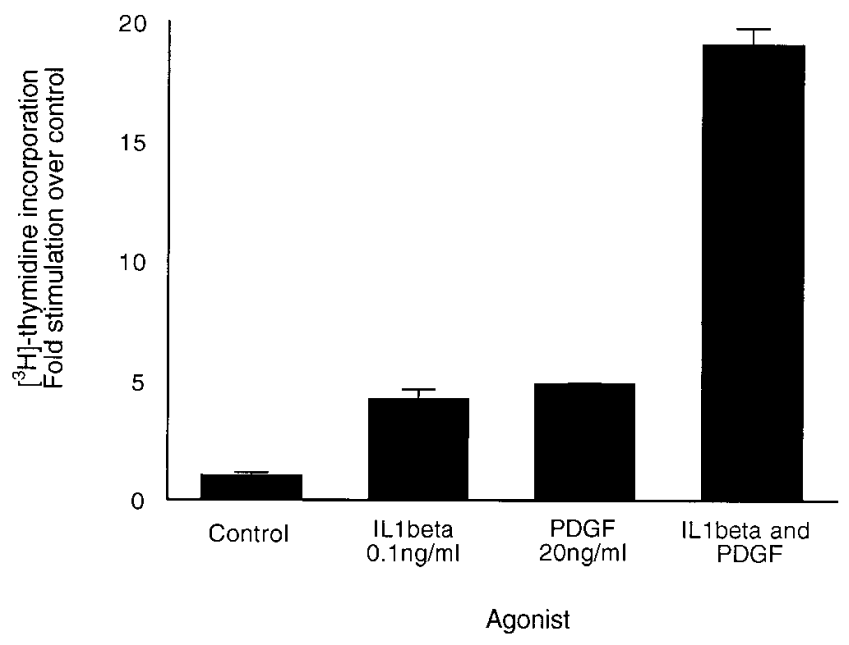

Figure 3. Proliferation of human colonic subepithelial myofibroblasts in response to interleukin $1 \beta$ : dose and time dependence. Significant $(P<0.05)$ increases in $\left[{ }^{3} \mathrm{H}\right]$ thymidine incorporation were seen with concentrations $\geq 0.01 \mathrm{ng} / \mathrm{ml}$ when present for $24(\mathbb{\square})$ or $32 \mathrm{~h}(\bigcirc)$. After $40 \mathrm{~h}(\square)$, the levels of $\left[{ }^{3} \mathrm{H}\right]$ thymidine incorporation had returned to basal (data for positive control of FCS $10 \%$ not shown). (b) $\left[{ }^{3} \mathrm{H}\right]$ thymidine incorporation in response to IL-1 $\beta$ (32 h), PDGF-BB $20 \mathrm{ng} / \mathrm{ml}(24 \mathrm{~h})$ or both. A marked increase was seen when both agonists were present.

incorporation had returned to basal levels over the entire range of concentrations of IL- $1 \beta$ tested $(1 \mathrm{pg} / \mathrm{ml}-10 \mathrm{ng} / \mathrm{ml})$. The effect of IL-1 $\beta(32 \mathrm{~h})$ at $0.1 \mathrm{ng} / \mathrm{ml}$ was synergistic with that of PDGF-BB ( 24 h, 20 ng/ml; Fig. $3 b)$. TNF- $\alpha$, another proinflammatory cytokine, also produced a dose- and time-dependent increase in $\left[{ }^{3} \mathrm{H}\right]$ thymidine incorporation, which at $24 \mathrm{~h}$ was $1.4 \pm 0.2$-fold over control $(\mathrm{TNF}-\alpha=100 \mathrm{ng} / \mathrm{ml})(n=4, P=$ $0.049)$. With agonist present for $32 \mathrm{~h}$, the response was more marked, with a peak of 3.4 \pm 0.24 -fold at $100 \mathrm{ng} / \mathrm{ml}(n=4, P=$ 0.002 ), and there was a significant elevation with concentrations as low as $0.1 \mathrm{ng} / \mathrm{ml}$, which was $1.5 \pm 0.06$-fold over control ( $n=4, P=0.01$ ) (data not shown). IL-6 and -10 induced no significant changes in $\left[{ }^{3} \mathrm{H}\right]$ thymidine incorporation either at 24,32 , or $40 \mathrm{~h}$ over the concentration range tested (0.1-100 $\mathrm{ng} /$ $\mathrm{ml}$ ), a positive control being provided by $10 \%$ FCS.
Table II. Change in Cell Number in Colonic Myofibroblasts over $72 \mathrm{~h}$ : Modulation by IL-1 $\beta$ and VIP

\begin{tabular}{lcc}
\hline \multicolumn{1}{c}{ Agonist } & $\begin{array}{c}\text { Percentage increase in cell number } \\
(\text { mean, } n=10) \text { c.f. 1\% FCS alone }\end{array}$ & $\begin{array}{c}95 \% \text { Confidence } \\
\text { intervals }\end{array}$ \\
\hline PDGF-BB $(20 \mathrm{ng} / \mathrm{ml})$ & 77.6 & $47-109$ \\
IL-1 $(0.1 \mathrm{ng} / \mathrm{ml})$ & 18.8 & $8.2-29$ \\
PDGF + IL-1 $\beta$ & 64.4 & $45-84$ \\
VIP $(1 \mu \mathrm{M})$ & 13.7 & $-1.6-29.8$ \\
PDGF + VIP & 68.2 & $41.8-97.9$ \\
& & \\
\hline
\end{tabular}

Changes in cell number determined with coulter counting, as described (Table I). PDGF was BB isoform, $20 \mathrm{ng} / \mathrm{ml}$, IL- $1 \beta$ was at $0.1 \mathrm{ng} / \mathrm{ml}$, VIP was $1 \mu \mathrm{M}$. Data represent mean of 10 experiments, with triplicate determinations in each, and are expressed relative to control wells containing $1 \%$ FCS alone.

Changes in cell number with IL-1 $\beta$ and PDGF-BB were then studied to determine whether the effects on $\left[{ }^{3} \mathrm{H}\right]$ thymidine incorporation were translated to changes in numbers of cells. Table II shows the results obtained in 10 experiments using PDGF-BB $(20 \mathrm{ng} / \mathrm{ml}), \mathrm{IL}-1 \beta(0.1 \mathrm{ng} / \mathrm{ml})$, or both agonists. As before, $1 \%$ FCS was included in all wells and the results expressed as percentage increase in cell numbers compared to wells incubated in control medium alone. In these experiments, PDGF-BB produced a significant increase in cell numbers. IL-1 $\beta$ alone produced a small increase in cell numbers that was significant $(P<0.05)$, but when it was added in combination with PDGF-BB, there was a trend towards a decrease in the response compared to PDGF-BB alone. This decrease was not statistically significant.

VIP opposes proliferative stimuli and elevates intracellular cyclic AMP in human colonic myofibroblasts. The neuropeptide VIP was investigated to determine its effect on proliferation of myofibroblasts in vitro. The effect of VIP on PDGFBB-driven proliferation is shown in Fig. 4. VIP at the highest concentration $(1 \mu \mathrm{M})$ caused no significant reduction in basal $\left[{ }^{3} \mathrm{H}\right]$ thymidine incorporation. It did, however, cause a significant reduction in the response to PDGF-BB (20 ng/ml for $24 \mathrm{~h}$ ) when added $10 \mathrm{~min}$ before the growth factor. The maximum inhibition of the response to PDGF-BB with $1 \mu \mathrm{M}$ VIP was $34 \pm 7 \%(n=12, P=0.002)$, and the $\mathrm{EC}_{50}$ for this response was approximately $2.2 \pm 0.3 \mathrm{nM}(n=12)$. Similarly, VIP $(1 \mu \mathrm{M})$ inhibited the response to IL- $1 \beta(0.1 \mathrm{ng} / \mathrm{ml}$ added for $32 \mathrm{~h})$ when added $10 \mathrm{~min}$ before this agonist by $48 \pm 8 \%(n=4, P=0.01)$. Because one possible mode of action for VIP is through activation of adenylate cyclase, we studied the effect of this agonist on intracellular cyclic AMP production. VIP produced a doserelated increase in cyclic AMP in human colonic myofibroblasts (Fig. 5), the $\mathrm{EC}_{50}$ for this response being $22 \pm 9 \mathrm{nM}(n=$ $4)$. The maximum stimulation observed was $3.4 \pm 0.2$ over control $(n=4, P=0.0004)$. A significant increase in cyclic AMP was seen at concentrations as low as $10 \mathrm{nM}$, consistent with the data shown for inhibition of $\left[{ }^{3} \mathrm{H}\right]$ thymidine incorporation in these cells. Finally, we looked for a change in cell numbers using VIP (Table II). VIP $(1 \mu \mathrm{M})$ alone produced no significant changes in cell numbers, although there was a trend towards an increase. When it was coincubated with PDGF-BB, there was a trend towards a decrease in cell numbers that did not reach significance. 


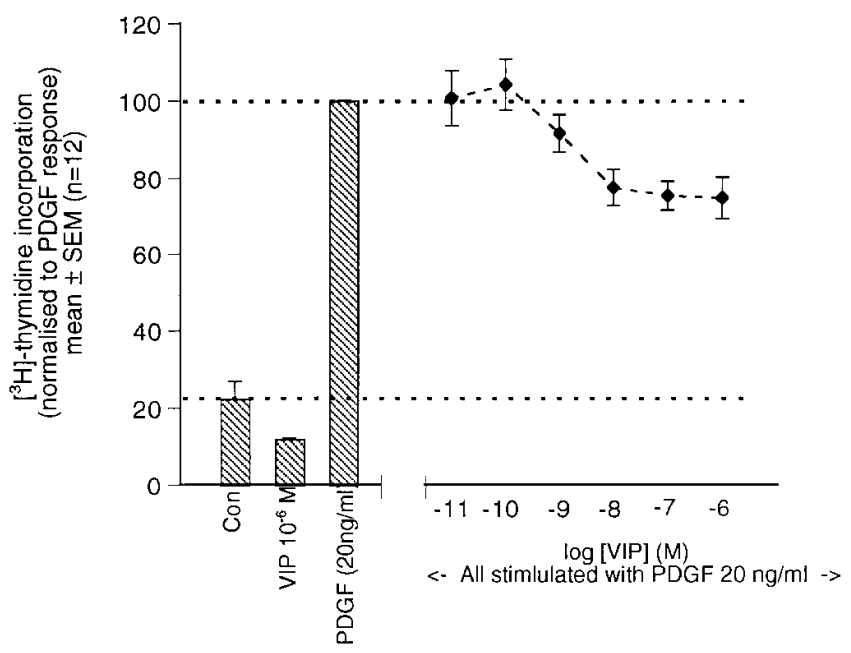

Figure 4. Inhibition of PDGF-BB-driven proliferation by vasoactive intestinal peptide $(V I P) .\left[{ }^{3} \mathrm{H}\right]$ thymidine incorporation in human colonic subepithelial myofibroblasts was measured in response to PDGF-BB stimulation $(20 \mathrm{ng} / \mathrm{ml})$ for $24 \mathrm{~h}$. VIP was added $10 \mathrm{~min}$ before the growth factor. A small but not significant decrease in basal thymidine incorporation was seen with VIP $10^{-6} \mathrm{M}$. VIP also caused a dose-related inhibition of the response to PDGF-BB. $(P<0.05$ for all concentrations $\geq 10 \mathrm{nM}$. All data are mean \pm SEM for 12 experiments (except VIP control $[n=4]$ and PDGF-BB \pm VIP $10^{-11}[n=$ $8])$. The mean $\mathrm{EC}_{50}$ for this response was $2.2 \pm 0.3 \mathrm{nM}(n=12)$.

\section{Discussion}

In the colon, there is a well recognized population of myofibroblasts resident beneath the basement membrane (27). Little is known about regulation of cell number in colonic myofibroblasts, but proliferation of similar cells in response to inflammation is seen in other tissues. It is not feasible to study the control of myofibroblast cell number in vivo in humans; hence, for longer term studies on proliferation and/or cell survival, it was necessary to develop an appropriate model. We have, therefore, used primary cultures of human colonic myofibroblasts to study the proliferative response to mediators believed to be important in the pathogenesis of inflammatory bowel disease. These cells exhibit phenotypic features in culture typical of myofibroblasts with actin and vimentin filaments demonstrated by immunofluoresence, and electron and light microscopic features of myofibroblasts.

Initial studies were designed to establish whether peptide growth factors PDGF-BB, bFGF, EGF, IGF-I and -II, which have a potentially important role in the pathogenesis of inflammatory bowel disease, act as mitogens for colonic subepithelial myofibroblasts, and also to determine their relative potencies and efficacies. PDGF-BB is widely recognized as a mediator of the inflammatory response (28) and is expressed in human colonic mucosa (4). In a model of ulcerative colitis in rats, PDGF-BB has been demonstrated to decrease the size and severity of ulcerated lesions and to induce reepithelization (29). Studies using immunofluoresence staining have shown bFGF expression in many tissues including the human gastrointestinal tract (5), whereas Satoh and colleagues report that it accelerated the healing of colonic lesions in $N$-ethylmaleimide-induced colitis in rats (30). The role for EGF in inflammatory bowel disease is unclear, but it is known to be a trophic factor in the gastrointestinal tract. EGF mRNA is found in both normal and ulcerative colitis colonic biopsies in humans (4), and EGF enhances resolution of ethanol/trinitrobenzenesulfonic acid-induced colitis in rats when given subcutaneously (31), whereas it has a protective effect in the same model when administered intraperitoneally (32). Finally, IGF-I is believed to play an important role in the development of fibrosis in the chronically inflamed intestine. IGF-I stimulates proliferation and collagen production in skin fibroblasts (33), and insulin (at concentration high enough to activate the IGF receptor) has also been shown to stimulate type III collagen production from fibroblasts derived from Crohn's disease strictures (34). In animal models of chronic intestinal inflammation, IGF-I mRNA expression is seen in subepithelial mesenchymal cells in areas of fibrosis (6), and it is synthesised by macrophages stimulated by proinflammatory cytokines such as IL-1 $\beta$ (35). In addition, there is upregulation of IGF-I and -II mRNA in specimens obtained from patients with either Crohn's disease or ulcerative colitis (5), although, in the latter disease, there seems to be little difference between involved and uninvolved areas. Therefore, there is good evidence that these peptides may be important in either wound repair or fibrotic reactions in the intestine: two key functions of myofibroblasts in disease.

In the studies described here, we found, using $\left[{ }^{3} \mathrm{H}\right]$ thymidine incorporation as an index of DNA synthesis, that PDGF-BB had the highest efficacy of all the mitogens tested with a maximum fold-stimulation over control of seven, which was unsurprising given that PDGF-BB is known to be an important mitogen in other myofibroblast-like systems (36). Although EGF and bFGF had significantly lower maximal responses in our system (i.e., lower efficacies), they were in fact more potent than PDGF-BB. The apparent $\mathrm{EC}_{50}$ seen with PDGF-BB was $14 \mathrm{ng} / \mathrm{ml}(0.6 \mathrm{nM})$, which was similar to that of EGF $(2.1 \mathrm{ng} / \mathrm{ml}$ $\sim 0.4 \mathrm{nM}$ ) in these cells but approximately twofold higher than previously reported in human airway smooth muscle (36).

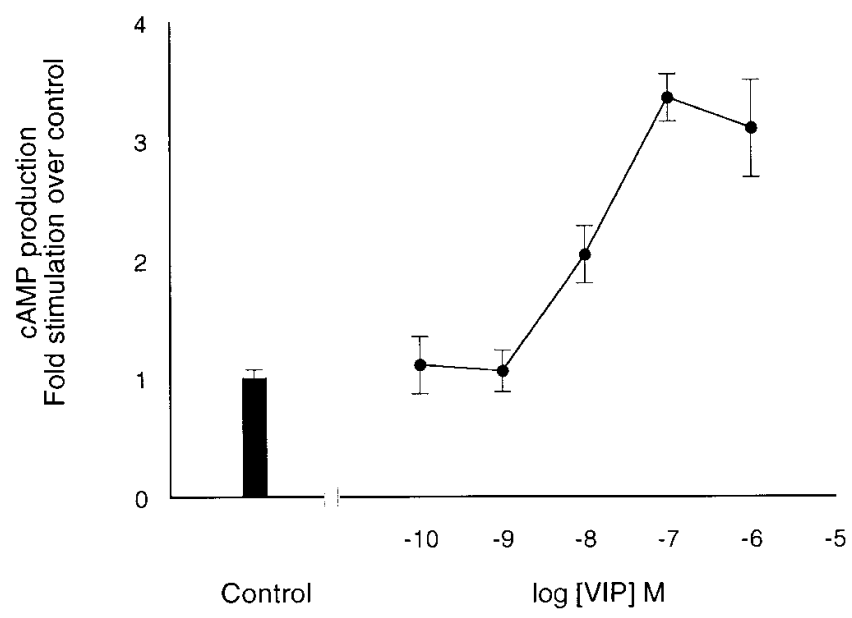

Figure 5. VIP activates adenylate cyclase. Confluent cells preincubated for $3 \mathrm{~h}$ with $\left[{ }^{3} \mathrm{H}\right]$ adenine were stimulated with varying concentrations of VIP for $30 \mathrm{~min}$. Reactions were terminated with concentrated $\mathrm{HCl}$ and cyclic AMP was extracted using column chromatography. Figure shows conversion of $\left[{ }^{3} \mathrm{H}\right]$ adenine to cyclic AMP after stimulation by VIP expressed as fold stimulation over control. The mean $\mathrm{EC}_{50}$ for this response was $22 \pm 9 \mathrm{nM}(n=4)$. 
bFGF was, however, significantly more potent with an $\mathrm{EC}_{50}$ for stimulation of $\left[{ }^{3} \mathrm{H}\right]$ thymidine incorporation in colonic myofibroblasts of $2.2 \mathrm{ng} / \mathrm{ml}(0.13 \mathrm{nM})(P<0.01$ compared with $\mathrm{EC}_{50}$ for EGF, $\left.n=4\right)$. The IGFs had relatively little effect on proliferation except at the highest concentrations, suggesting that they are not important mitogens for these cells.

When these data were compared with changes in cell number, significant discrepancies were noted. At $20 \mathrm{ng} / \mathrm{ml}$, there was no significant difference between PDGF-BB, EGF, and bFGF in their ability to increase cell number. Interestingly, at these doses (at which no increase in thymidine incorporation was seen) both IGF-I and -II caused significant increases in cell number over $72 \mathrm{~h}$. Differences between $\left[{ }^{3} \mathrm{H}\right]$ thymidine incorporation and other measures of proliferation or cell cycle progression are well recognized. Incomplete mitogens have been characterized (e.g., EGF in porcine aortic smooth muscle cells (37) where the growth factor potently stimulates $G_{0} \rightarrow$ $\mathrm{S}$-phase progression, but does not lead to mitosis) and this phenomenon may in part explain the difference in relative efficacies of PDGF-BB and EGF, or bFGF at $20 \mathrm{ng} / \mathrm{ml}$ when thymidine incorporation is compared with cell number data, if PDGF-BB is acting as a partial mitogen. For IGF-I and -II to produce increases in cell number without changes in thymidine incorporation, an alternative explanation is required. IGF-I may be acting synergistically with other factors present in the medium in the cell number experiments, as $1 \%$ FCS was required in these experiments to prevent cell death in the control wells over $72 \mathrm{~h}$. In other smooth muscle cell systems, IGF-I has been reported to act synergistically with bFGF (38), a component of FCS. Alternatively, IGF-I may be acting as a survival factor. There is good evidence (39) that IGF-I protects myofibroblast-like cells from other tissues from undergoing apoptosis and, in our system, there is likely to be a balance between basal proliferation rates and cell death in the presence of $1 \%$ FCS. Protecting cells from apoptosis will clearly allow the cell number to increase as proliferation predominates. Further experiments will be necessary to define more precisely which agents inhibit apoptosis by providing a survival signal in this system. It is clear, however, that all the above growth factors increase cell number and, therefore, may be important in wound repair and fibrosis.

We also examined the contribution to myofibroblast proliferation of the potent proinflammatory cytokines TNF- $\alpha$ and IL-1 $\beta$ produced by macrophages in the inflamed colon. There is good evidence that these cytokines mediate inflammatory responses in many tissues and there is evidence for upregulation of TNF- $\alpha$ and IL-1 $\beta$ activity in both ulcerative colitis and Crohn's disease $(8,9)$. In other smooth muscle or myofibroblast cell culture models, both these cytokines have been shown to increase DNA synthesis and, in our model, we found similar results, although this was only apparent at longer timepoints than the other growth factors studied. IL-1 $\beta$ also produced a significant increase in cell number after an incubation period of $72 \mathrm{~h}$. This would suggest that myofibroblast proliferation is driven by this proinflammatory cytokine. In other models, synergy between IL- $1 \beta$ and growth factors such as PDGF-BB has been seen; for example, IL-1 $\beta$ upregulates PDGF-BB receptor expression leading to enhanced responses to this growth factor $(40)$. The data we obtained with $\left[{ }^{3} \mathrm{H}\right]$ thymidine incorporation strongly suggest synergy, as the combined effect of the two cytokines is significantly greater than the sum of the two responses when cytokines were added sepa- rately. When cell number was examined, however, there was no significant difference between PDGF-BB with IL-1 $\beta$ and PDGF-BB alone. As already discussed, this may be due to discrepancies between entry into S-phase and mitosis, or due to differential effects on cell survival. TNF- $\alpha$ had similar effects to IL-1 $\beta$ on $\left[{ }^{3} \mathrm{H}\right]$ thymidine incorporation in colonic myofibroblasts. Two other cytokines that are known to be upregulated locally in inflammatory bowel disease (IL-6 and IL-10) were also examined for an effect on DNA synthesis. No increase in $\left[{ }^{3} \mathrm{H}\right]$ thymidine incorporation was found at a range of concentrations $(0.1-100 \mathrm{ng} / \mathrm{ml})$ over incubation periods of $24-40 \mathrm{~h}$, confirming a selective response of myofibroblasts to the proinflammatory 'master' cytokines IL- $1 \beta$ and TNF- $\alpha$.

We next studied the possibility that the mitogenic effects of growth factors may be negatively regulated by VIP. It is unlikely that proliferative stimuli act unopposed in vivo. In myofibroblast-like cells derived from other tissues, agents that elevate cyclic AMP can downregulate responses to proliferative stimuli. One candidate molecule in the colon is VIP, which has been demonstrated to partially inhibit proliferation in human airway smooth muscle cells by a cyclic AMP-dependent mechanism (41). Sources in the colon include both the myenteric plexus, the nerves of which terminate in the lamina propria, and inflammatory cells (15). There appears to be destruction of VIP-containing nerves in the transmural inflammation of Crohn's disease (42), and it has been reported that there are significant decreases in tissue content of VIP in ulcerative colitis (43). It has been demonstrated, however, that eosinophils derived from inflamed colonic mucosa produce VIP in culture (44). Our data on DNA synthesis would be consistent with the hypothesis that VIP modulates the inflammatory response by restraining myofibroblast proliferation in response to inflammatory mediators, although the effect on cell numbers was small and did not reach significance. One potential mechanism for VIP acting to retard proliferation is via elevation of intracellular cyclic AMP. We have confirmed this action of VIP in colonic myofibroblasts in culture over doses similar to those which inhibit $\left[{ }^{3} \mathrm{H}\right]$ thymidine incorporation. The possibility that pharmacological manipulation of cell cyclic AMP content could modulate remodeling in the colon during inflammation is worth further study and has clear therapeutic implications.

In conclusion, we have used a novel model system for studying the proliferative responses of human colonic subepithelial myofibroblasts and defined factors that promote proliferation of these cells in vitro. We have used both $\left[{ }^{3} \mathrm{H}\right]$ thymidine incorporation and Coulter counting to follow changes in cell numbers and have demonstrated that a range of important mediators in the gut can act as mitogens for these cells. We have also demonstrated that these responses may be inhibited by elevation of intracellular cyclic AMP induced by stimulation with VIP. Finally, we have observed discrepancies between DNA synthesis and change in cell number, suggesting that these mediators may also modulate cell survival/apoptosis in addition to their direct effects on mitogenic responses, which will require further investigation.

\section{Acknowledgments}

We are grateful to Y.R. Mahida (Division of Gastroenterology, University Hospital, Nottingham) for supplying human colonic subepithelial myofibroblasts used in these studies.

T.M. Jobson is a Wellcome Trust Research Training Fellow. I.P. 
Hall is a National Asthma Campaign Senior Fellow. This work was supported by a grant from the Wellcome Trust.

\section{References}

1. Desmouliere, A., M. Redard, I. Darby, and G. Gabbiani. 1995. Apoptosis mediates the decrease in cellularity during the transition between granulation tissue and scar. Am. J. Pathol. 146:55-66.

2. Schmitt-Graff, A., A. Desmouliere, and G. Gabbiani. 1994. Heterogeneity of myofibroblast phenotypic features: an example of fibroblastic cell plasticity. Virchows Archiv. 425:3-24.

3. Misiewicz, J.J., C.I. Bartram, P.B. Cotton, A.S. Mee, A.B. Price, and R.P.H. Thompson. 1988. Ulcerative colitis. In Diseases of the Colon and Rectum: A Guide to Diagnosis. Gower Medical Publishing, London, U.K. 62-94.

4. Chowdhury, A., R. Fukuda, and S. Fukumoto. 1996. Growth factor mRNA expression in normal colorectal mucosa and in uninvolved mucosa from ulcerative colitis patients. J. Gastroenterol. 13:353-360.

5. Cordon-Cardo, C., I. Vlodavsky, A. Haimovitz-Friedman, D. Hicklin, and Z. Fuks. 1990. Expression of basic fibroblast growth factor in normal human tissues. Lab. Invest. 63:832-840.

6. Zimmermann, E.M., K. McNaughton, R.B. Sartor, and P.K. Lund. 1993. IGF-I is over expressed in cells with a smooth muscle phenotype in peptidoglycan-polysaccharide induced chronic enterocolitis in the rat. Gastroenterology. 104:A808. (Abstr.)

7. Stewart, C.E.H., and P. Rotwein. 1996. Insulin-like growth factor-II is an autocrine survival factor for differentiating myoblasts. J. Biol. Chem. 271: 11330-11338.

8. Mahida, Y.R., K. Wu, and D.P. Jewell. 1989. Enhanced production of interleukin $1 \beta$ by mononuclear cells isolated from mucosa with active ulcerative colitis or Crohn's disease. Gut. 30:835-838.

9. Reinecker, H.C., M. Steffen, T. Witthoef, I. Pflueger, S. Schreiber, R.P. MacDermott, and A. Raedler. 1993. Enhanced secretion of tumour necrosis factor-alpha, IL-6 and IL-1beta by isolated lamina propria mononuclear cells from patients with ulcerative colitis and Crohn's disease. Clin. Exp. Immunol. 94:174-181.

10. Wardle, T.D., and L.A. Turnberg. 1994. Potential role for interleukin-1 in the pathophysiology of ulcerative colitis. Clin. Sci. 86:619-626.

11. Niessner, M., and B.A. Volk. 1995. Altered Th1/Th2 cytokine profiles in the intestinal mucosa of patients with inflammatory bowel disease as assessed by quantitative reversed transcribed polymerase chain reaction (RT-PCR). Clin. Exp. Immunol. 101:428-435.

12. Schreiber, S., T. Heinig, H.G. Thiele, and A. Raedler. 1995. Immunoregulatory role of interleukin 10 in patients with inflammatory bowel disease. Gastroenterology. 108:1434-1444.

13. Shanahan, F., and P. Anton. 1988. Neuroendocrine modulation of the immune system. Possible implications for inflammatory bowel disease. Dig. Dis. Sci. 33:415-495.

14. Polak, J.M., and S.R. Bloom. 1982. Localisation of regulatory peptides in the gut. Br. Med. Bull. 38:303-308.

15. Metwali, A., A.M. Blum, L. Ferraris, J.S. Klein, C. Fiocchi, and J.V. Weinstock. 1994. Eosinophils within the healthy or inflamed human intestine produce substance P and vasoactive intestinal peptide. J. Neuroimmunol. 52: 69-78.

16. Tomlinson, P.R., J.W. Wilson, and A.G. Stewart. 1995. Salbutamol inhibits the proliferation of human airway smooth muscle cells grown in culture: relationship to elevated cAMP levels. Biochem. Pharmacol. 49:1809-1819.

17. Valentich, J.D., and D.W. Powell. 1994 Intestinal sub-epithelial myofibroblasts and mucosal immunophysiology. Curr. Opin. Gastroenterology. 10: 645-651.

18. Owens, M.W., and M.B. Grisham. 1993. Cytokines increase proliferation of human intestinal smooth muscle cells: possible role in inflammationinduced stricture formation. Inflammation. 17:481-487.

19. Graham, M.F., G.R. Bryson, and R.F. Diegelmann. 1989. Interleukin-1 is a mitogen for and selectively augments collagen production by human intestinal smooth muscle cells. Gastroenterology. 106:A181. (Abstr.)

20. Mahida, Y.R., J. Beltinger, S. Makh, M. Goke, T. Gray, D.K. Podolsky, and C.J. Hawkey. 1997. Adult human colonic subepithelial myofibroblasts express extracellular matrix proteins and cyclooxygenase-1 and -2. Am. J. Physiol. 273:G1341-G1348.

21. Mahida, Y.R., A.M. Galvin, T. Gray, S. Makh, M.E. McAllindon, H.F. Sewell, and D.K. Podolosky. 1997. Migration of human intestinal lamina propria lymphocytes, macrophages and eosinophils following loss of surface epi- thelial cells. Clin. Exp. Immunol. 109. 377-386.

22. Danielpour, D., L.L. Dart, K.C. Flanders, A.B. Roberts, and M.B. Sporn. 1989. Immunodetection and quantitation of the two forms of transforming growth factor beta (TGF-beta1 and TGF-beta2) secreted by cells in culture. J. Cell. Physiol. 138:79-86.

23. Hall, I.P., S. Widdop, P. Townsend, and K. Daykin. 1992. Control of cyclic AMP levels in primary cultures of human tracheal smooth muscle cells. $\mathrm{Br}$. J. Pharmacol. 107:422-428.

24. Donaldson, J., S.J. Hill, and A.M. Brown 1988. Kinetic studies on the mechanism by which histamine H1 receptors potentiate cyclic AMP accumulation in guinea-pig cerebral cortical slices. Mol. Pharmacol. 33:626-633.

25. Daniel, W.W. 1995. Biostatistics: A Foundation for Analysis in the Health Sciences. Sixth edition. John Wiley \& Sons, Inc., New York. 780 pp.

26. Skalli, O., W. Schurch, T. Seemayer, R. Lagace, D. Montandon, B. Pittet, and G. Gabbiani. 1989. Myofibroblasts from diverse pathologic settings are heterogeneous in their content of actin isoforms and intermediate filament proteins. Lab Invest. 60:275-285.

27. Kaye, G.I., N. Lane, and R.R. Pascal. 1968. Colonic pericryptal fibroblast sheath: replication, migration and cytodifferentiation of a mesenchymal cell system in adult tissue. II. Fine structural aspects of normal rabbit and human colon. Gastroenterology. 54:852-865.

28. Abboud, H.E. 1993. Growth factors in glomerulonephritis. Kidney Int. 43:252-57.

29. Sandor, Z., D. Szeli, M. Charette, and S. Szabo. 1995. Platelet derived growth factor accelerates the healing of experimental ulcerative colitis in rats. Gastroenterology. 108:A887. (Abstr.)

30. Satoh, H., K. Takami, K. Kato, J. Folkman, and S. Szabo. 1990. Effect of bFGF and its motein on healing of colonic ulcers induced by N-ethylmaleimide in rats. Gastroenterology. 98:A203. (Abstr.)

31. Luck, M.S., and P. Bass. 1993. Effect of epidermal growth factor on experimental colitis in the rat. J. Pharmacol. Exp. Ther. 264:984-990.

32. Procaccino, F., M. Reinshagen, P. Hoffmann, J.M. Zech, J. Lakshmanan, J.A. McRoberts, A. Patel, S. French, and V.E. Eysselein. 1994. Protective effect of epidermal growth factor in an experimental model of colitis in rats. Gastroenterology. 107:12-17.

33. Clemmons, D.R., and D.S. Shaw. 1986. Purification and biological properties of fibroblast somatomedin. J. Biol. Chem. 261:10293-10298.

34. Stallmach, A., D. Schuppan, H.H. Riese, H. Matthes, and E.O. Riecken. 1992. Increased collagen synthesis by fibroblasts isolated from strictures of patients with Crohn's disease. Gastroenterology. 102:1920-1929.

35. Kirstein, M., C. Aston, R. Hintz, and H. Vlassara. 1992. Receptor specific induction of insulin-like growth factor I in human monocytes by advanced glycosylation and product-modified proteins. J. Clin. Invest. 90:439-446.

36. Hirst, S.J., P.J. Barnes, and C.H.C. Twort. 1996. PDGF isofrom-induced proliferation and receptor expression in human cultured airway smooth muscle cells. Am. J. Physiol. 270:L415-L428.

37. Bagby, S.P., M.M. O'Reilly, E.A. Kirk, L.H. Mitchell, P.E. Stenberg, M.T. Makler, and A.C. Bakke. 1992. EGF is incomplete mitogen in porcine aortic smooth muscle cells: DNA synthesis without cell division. Am. J. Physiol. 262:C578-C588.

38. Reape, T.J., J.M. Kanzcler, J.P.T. Ward, and C.R. Thomas. 1996. IGF-I increases bFGF induced mitogenesis and upregulates FGFR-1 in rabbit vascular smooth muscle cells. Am. J. Physiol. 270:H1141-H1148.

39. Mooney, A., T. Jobson, R. Bacon, M. Kitamura, and J. Savill. 1997. Cytokines promote glomerular mesangial cell survival in vitro by stimulus-dependent inhibition of apoptosis. J. Immunol. 159(8):3949-3960.

40. Tsukamoto, T., T. Matsui, H. Nakata, M. Ito, T. Natazuka, M. Fukase, and T. Fujita. 1991. Interleukin-1 enhances the response of osteoblasts to platelet-derived growth factor through the alpha receptor-specific up-regulation. $J$. Biol. Chem. 266:10143-10147.

41. Maruno, K., A. Absood, and S.I. Said. 1995. VIP inhibits basal and histamine-stimulated proliferation of human airway smooth muscle cells. Am. J. Physiol. 268:L1047-L1051.

42. Bishop, A.E., J.M. Polak, M.G. Bryant, S.R. Bloom, and S. Hamilton. 1980. Abnormalities of vasoactive intestinal polypeptide-containing nerves in Crohn's Disease. Gastroenterology. 79:853-860.

43. O’Morain, C., A.E. Bishop, G.P. McGregor, A.J. Levi, S.R. Bloom, J.M. Polak, and T.J. Peters. 1984. Vasoactive intestinal peptide concentrations and immunocytochemical studies in rectal biopsies from patients with inflammatory bowel disease. Gut. 25:57-61.

44. Metwali, A., A.M., Blum, L. Ferraris, J.S. Klein, C. Fiocchi, and J.V. Weinstock. 1994. Eosinophils within the healthy or inflamed human intestine produce substance $\mathrm{P}$ and vasoactive intestinal peptide. J. Neuroimmunol. 52(1): 69-78. 